\title{
The Basic Learning Model of Traditional Motion Based Games for Early Childhood (5-6) Years
}

\author{
Nofi Marlina Siregar, Eka Fitri Novita Sari*, Marlinda Budiningsih, Zulham \\ Department of Physical Education, Universitas Negeri Jakarta, Jln Pemuda 10 Rawamangun Jakarta Timur, Indonesia
}

Received September 22, 2020; Revised December 10, 2020; Accepted December 20, 2020

\section{Cite This Paper in the following Citation Styles}

(a): [1] Nofi Marlina Siregar, Eka Fitri Novita Sari, MarlindaBudiningsih, Zulham , "The Basic Learning Model of Traditional Motion Based Games for Early Childhood (5-6) Years," International Journal of Human Movement and Sports Sciences, Vol. 9, No. 1, pp. 81-88, 2021. DOI: 10.13189/saj.2021.090111.

(b): Nofi Marlina Siregar, Eka Fitri Novita Sari, MarlindaBudiningsih, Zulham (2021). The Basic Learning Model of Traditional Motion Based Games for Early Childhood (5-6) Years. International Journal of Human Movement and Sports Sciences, 9(1), 81-88. DOI: 10.13189/saj.2021.090111.

Copyright $\odot 2021$ by authors, all rights reserved. Authors agree that this article remains permanently open access under the terms of the Creative Commons Attribution License 4.0 International License

\begin{abstract}
This study aims to create a basic motion model of traditional games based on early childhood games (5-6) years. The aim of research is to create models and improve basic movements of early childhood education, especially those related to locomotor, non-locomotor and manipulative movements in early childhood (5-6) years. This research used a research and development (R\&D) method which was carried out in DKI Jakarta with small experiment on 10 children and large experiment on 30 children by applying 20 basic movements based on traditional games. Based on the results of the effectiveness test on 30 research subjects, the initial test results of children's activities in motion were 12.8 and in the final test 20 , there was an increase in children's activities in motion. The results of the initial test of children's activeness in nonmotorized motion were 13.66 and in the final test 16.8 there was an increase in children's activeness in non-motorized movement. The initial test of children's activeness in manipulative movements was 19.7 and the final test 22, there was an increase in children's activeness in manipulative movements. Based on the results of the above research, basic motion models based on traditional games for early childhood (5-6) years old can be applied as well as effective basic motion models to increase activities, abilities and skills through movement, especially those related to basic locomotor motion techniques, non locomotor and manipulative.
\end{abstract}

Keywords Basic Movement, Early Childhood, Traditional Games

\section{Introduction}

Children are unique individuals. Many experts have observed that the abilities of infants and toddlers are extraordinary in various aspects of their development. From the point of view of language development, children are fast learners in absorbing vocabulary, grasping meaning and mastering language, even multiple languages at once. In the physical aspect, children experience rapid growth of functional abilities, from lying down, prone, crawling, sitting, standing, walking, walking and so on. From a social point of view, children are innocent imitators of the social behavior of those around them. From an emotional point of view, children are forming partnerships themselves through reflection from the environment, likewise from various other development angles.

A child experiences very rapid development in various aspects of his personality, both physically and mentally. Children have a lot of pleasure in receiving various stimuli that will affect their brain function. The development of children's cognition greatly determines the functioning of other aspects of development. The brain as the control center controls all functions and abilities in the activities of the body, both psychologically and physically.

Children get intelligence or knowledge from the environment by moving. Moving is the most dominant way to know the environment. For children at an early, playing is the main behavior and activity, while moving is one of the basic needs and basic means of expressing 
themselves.

Movement development takes place from birth to elementary school age, where at an early age physical motor development is in its infancy. Along with that, the basic movements need to be considered by an educator at school so that they can grow optimally.

Actually, children do not need to be told or stimulated to move, because automatically the children will be happy to make movements. That's when we as educators pay attention to how basic locomotor, non-locomotor and manipulative movements develop optimally.

Games that require running and catching something (for example: catching a person or a ball) not only improve motor skills, reaction speed and defense ability, but can also improve children's basic movement skills.

The form of play should include all basic movements, such as: stepping, walking, jumping, jumping, crawling, climbing, rolling, pulling, swinging, throwing and catching. These movements can be developed from traditional games, where children can get to know the games from each region, so it is hoped that children can like and apply traditional games. Therefore, the above researchers have an interest in making a study on "Basic Motion Learning Model Based on Traditional Games for Early Childhood (5-6) years.

\section{Material and Methods}

This research and development uses quantitative and qualitative approaches and uses the Research \& Development (R \& D) development model from Borg and Gall $^{1}$ which consists of ten steps. The research begins by collecting data in the form of a needs analysis. Where the needs analysis will describe the needs of the research subject problem.

The Basic Learning Model of Traditional Motion Games for Early Childhood (5-6) Years is part of development research which aims to create a basic motion learning model based on traditional games in early childhood. Carried out in DKI Jakarta with as many as 10 children in the small trial and 30 children in the large trial by applying 20 basic movements based on traditional games, basic locomotor, non-locomotor and manipulative based motion test instruments traditional game.

\section{Research and Information}

Determination of potential problems in early childhood education, when researchers make initial observations in the field, during the observation, the researcher found various problems such as in providing learning that was not in accordance with the characteristics of the child, namely playing and moving. Was still adult, teacher-centered, so that in overcoming the above

\footnotetext{
${ }^{1}$ Borg W. R, \& Gall M. D, Educational Research: An Introduction. Fourth Edition (New York: Longman, 1983), h.775
}

problems, the researcher will create a physical activity model based on basic movement intelligence based on traditional games for early childhood (5-6) years, based on preliminary studies conducted by researchers in the field by conducting observation and interview techniques

Next, the researcher made a game design based on the indicators to be aimed at, namely the basic movements of the The researcher makes preparations for the subject and place of research, makes the media to be used, coordinates the subject and the place of research as well as the teachers and facilitators who will assist in carrying out the research..

\section{Develop Preliminary Form of Product}

Research can be started from potential problems as needed in the environment. The step is taken to find any information that is important for the product to be developed. This stage includes steps in the form of analysis, analysis and small-scale research to support the perfection of this initial stage. These steps are (1) needs analysis and literature study of research problems, (2) identification of literature studies, carried out to temporarily realize the product to be developed, and (3) small- scale research.

In this stage, the initial product is made in the form of a basic motion model based on traditional games for early childhood.

\section{Preliminary Field Testing}

This stage is to conduct field trials in the early stages using the subject to see the level of the product being made and to provide the model expert sheet with the models. Each expert is asked to assess the design of the model, so that further weaknesses and strengths can be found to analyze them. The researcher coordinates with the early childhood expert, Dr. lilis Suryani and early childhood physical activity expert, Eka Fitri Novitasari, M.Pd

\section{Main Product Revision}

The revision of the design at this stage was carried out based on input from the results of the experts; the results of the early stage field tests were made improvements to these models. Researchers made improvements according to the results during the initial trials and input from experts.

\section{Main Field Testing}

At this stage, the main field trial stage is carried out with two stages of small product trials and large product trials.

This test can compare effectiveness and efficiency.

\section{Operational Product Revision}

This stage is the stage of revising operational products based on input from expert suggestions as well as the results of the main field tests. 


\section{Operational field Testing}

In this operational field trial stage, data collected through interviews and observations.

\section{Final Product Revision}

Make revisions to the final product based on suggestions from experts and based on previous field trials.

\section{Dissemination and Implementation}

Implementing and disseminating products through international seminars. Cooperate with publishers for product and commercial socialization and monitor distribution control.

Table 1. Basic motion (locomotor)

\begin{tabular}{|c|c|c|c|c|}
\hline \multirow[b]{2}{*}{ No } & \multirow[b]{2}{*}{ Ability } & \multicolumn{3}{|c|}{ Score } \\
\hline & & $\begin{array}{c}\text { Poor } \\
\text { (1) }\end{array}$ & $\begin{array}{l}\text { Average } \\
\text { (2) }\end{array}$ & $\begin{array}{l}\text { Good } \\
\text { (3) }\end{array}$ \\
\hline 1 & $\begin{array}{l}\text { Walk forward in a } \\
\text { straight line. }\end{array}$ & $\begin{array}{c}\text { The child can move forward in a } \\
\text { straight line as far as } 3-4 \mathrm{~m} \text { without a } \\
\text { straight view, swinging the legs and } \\
\text { arms out of sync. }\end{array}$ & \begin{tabular}{|c|} 
Children can walk forward in a straight \\
line as far as 3-4 m with a straight gaze, \\
swing legs and arms are not in sync or \\
gaze is not straight, \\
swing legs and arms in harmony. \\
\end{tabular} & $\begin{array}{c}\text { The child can walk forward in a } \\
\text { straight line as far as } 3-4 \text { m with a } \\
\text { straight gaze, swinging the legs } \\
\text { and arms in sync. }\end{array}$ \\
\hline 2 & $\begin{array}{l}\text { Walk on the } \\
\text { footbridge. }\end{array}$ & $\begin{array}{c}\text { The child cannot walk with a } \\
\text { balanced body position and may fall. }\end{array}$ & $\begin{array}{c}\text { Children can walk with an unbalanced } \\
\text { body position and do not fall. }\end{array}$ & $\begin{array}{c}\text { Children can walk with a } \\
\text { balanced body position and do } \\
\text { not fall. }\end{array}$ \\
\hline 3 & $\begin{array}{c}\text { Walk on tiptoe in a } \\
\text { straight line. }\end{array}$ & $\begin{array}{l}\text { Children cannot walk on tiptoe in a } \\
\text { straight line. }\end{array}$ & $\begin{array}{c}\text { Children can walk on tiptoe in a straight } \\
\text { line with an unbalanced body } \\
\text { position. }\end{array}$ & $\begin{array}{c}\text { Children can walk on tiptoe in a } \\
\text { straight line with a balanced } \\
\text { body position. }\end{array}$ \\
\hline 4 & $\begin{array}{l}\text { Walk backwards in a } \\
\text { straight line. }\end{array}$ & $\begin{array}{c}\text { The child cannot walk backwards in } \\
\text { straight line } 2 \text { meters away by } \\
\text { making one or more glances. }\end{array}$ & \begin{tabular}{|c|}
$\begin{array}{c}\text { The child can walk backwards in a } \\
\text { straight line for } 2 \text { meters by making } \\
\text { one or more glances. }\end{array}$ \\
\end{tabular} & $\begin{array}{c}\text { The child can walk backwards in } \\
\text { a straight line up to } 2 \text { meters with } \\
\text { a forward gaze. }\end{array}$ \\
\hline 5 & $\begin{array}{c}\text { Step to the right side } \\
\text { in a straight line. }\end{array}$ & $\begin{array}{l}\text { The child cannot step to the right side } \\
\text { in a straight line 2-3 meters away. }\end{array}$ & $\begin{array}{l}\text { The child can step to the right side in a } \\
\text { straight line 2-3 meters away with one } \\
\text { or more loss of direction. }\end{array}$ & \begin{tabular}{|c|} 
The child can step to the right \\
side in a straight line for $2-3$ \\
meters without losing direction.
\end{tabular} \\
\hline 6 & $\begin{array}{c}\text { Step left in a straight } \\
\text { line. }\end{array}$ & $\begin{array}{l}\text { The child cannot step to the left side } \\
\text { in a straight line 2-3 meters away. }\end{array}$ & $\begin{array}{l}\text { The child may step to the left side in a } \\
\text { straight line 2-3 meters away with one } \\
\text { or more loss of direction. }\end{array}$ & $\begin{array}{c}\text { The child can step to the left in a } \\
\text { straight line for } 2-3 \text { meters } \\
\text { without losing direction. }\end{array}$ \\
\hline 7 & Run straight ahead. & $\begin{array}{l}\text { The child cannot run straight ahead } \\
\text { with irregular swinging of his legs } \\
\text { and arms, not looking forward. }\end{array}$ & $\begin{array}{l}\text { The child can run straight ahead with } \\
\text { swinging legs and arms out of tune, } \\
\text { looking forward. }\end{array}$ & $\begin{array}{c}\text { The child can run straight ahead } \\
\text { with swinging legs and arms in } \\
\text { sync, looking forward. }\end{array}$ \\
\hline
\end{tabular}

Table 2. Basic motion (non-locomotor)

\begin{tabular}{|c|c|c|c|c|}
\hline \multirow[b]{2}{*}{ No } & \multirow[b]{2}{*}{ Ability } & \multicolumn{3}{|c|}{ Score } \\
\hline & & $\begin{array}{c}\text { Poor } \\
\text { (1) }\end{array}$ & $\begin{array}{l}\text { Average } \\
\text { (2) }\end{array}$ & $\begin{array}{c}\text { Good } \\
\text { (3) }\end{array}$ \\
\hline 1 & $\begin{array}{c}\text { Sitting position with } \\
\text { straight legs, hands } \\
\text { touching toes. }\end{array}$ & $\begin{array}{l}\text { The child cannot touch the toes with } \\
\text { the hands. }\end{array}$ & $\begin{array}{c}\text { The child can touch the toes with } \\
\text { both hands, knees bent. }\end{array}$ & $\begin{array}{l}\text { The child can touch the toes with both } \\
\text { hands, knees straight. }\end{array}$ \\
\hline 2 & Lean to the right side. & $\begin{array}{l}\text { The child can lean to the right, right } \\
\text { hand on the leg, fingertips touching } \\
\text { up above the knee. }\end{array}$ & $\begin{array}{l}\text { The child can lean to the right, right } \\
\text { hand on the leg, fingertips touching } \\
\text { up to the knee. }\end{array}$ & $\begin{array}{l}\text { The child can lean over to the right, } \\
\text { right hand on the leg, fingertip } \\
\text { touching below the knee. }\end{array}$ \\
\hline 3 & Learn to the left side. & $\begin{array}{c}\begin{array}{c}\text { The child can lean to the right, left } \\
\text { hand on the leg, fingertips touching } \\
\text { up above the knee. }\end{array} \\
\end{array}$ & \begin{tabular}{|c|}
$\begin{array}{r}\text { The child can lean to the left, right } \\
\text { hand on the leg, fingertip touching } \\
\text { up to the knee. }\end{array}$ \\
\end{tabular} & $\begin{array}{l}\text { The child can lean to the left hand, the } \\
\text { left hand resting on the leg, the } \\
\text { fingertip touching below the knee. }\end{array}$ \\
\hline 4 & $\begin{array}{c}\text { Turn the body to the } \\
\text { right. }\end{array}$ & $\begin{array}{c}\text { The child can rotate the body to the } \\
\text { right side with both hands holding } \\
\text { less than } 45 \text { degrees. }\end{array}$ & $\begin{array}{c}\text { The child can turn to the right side } \\
\text { with both hands holding from } 45 \\
\text { s.d. } 90 \text { degrees. }\end{array}$ & $\begin{array}{l}\text { The child can turn to the right side } \\
\text { with both hands holding more than } \\
90 \text { degrees. }\end{array}$ \\
\hline 5 & $\begin{array}{c}\text { Turn the body to the } \\
\text { left. }\end{array}$ & $\begin{array}{l}\text { The child can rotate the body to the } \\
\text { left side with both hands holding less } \\
\text { than } 45 \text { degrees. }\end{array}$ & \begin{tabular}{|c|}
$\begin{array}{c}\text { The child can turn to the left side } \\
\text { with both hands holding from } 45 \\
\text { s.d. } 90 \text { degrees }\end{array}$ \\
\end{tabular} & $\begin{array}{c}\text { The child can rotate the body to the } \\
\text { left side with both hands holding } \\
\text { more than } 90 \text { degrees. }\end{array}$ \\
\hline
\end{tabular}


Table 3. Basic motion (manipulative)

\begin{tabular}{|c|c|c|c|c|}
\hline \multirow{2}{*}{ No } & \multirow{2}{*}{ Ability } & \multicolumn{3}{|c|}{ Score } \\
\hline & & Poor (1) & Average (2) & Good (3) \\
\hline 1 & $\begin{array}{l}\text { Throwing the big ball } \\
\text { with both hands up. }\end{array}$ & $\begin{array}{l}\text { The child can throw the big ball, the } \\
\text { position of one foot is in front, the } \\
\text { view is forward, the body is not } \\
\text { bouncy, the ball is released above the } \\
\text { head without further hand } \\
\text { movements. }\end{array}$ & $\begin{array}{l}\text { Children can throw a big ball, } \\
\text { position one foot in front, look } \\
\text { forward, body bouncy, the ball is } \\
\text { released above the head without } \\
\text { further hand movements. }\end{array}$ & $\begin{array}{l}\text { Children can throw a big ball, } \\
\text { position one foot in front, look } \\
\text { forward, body bouncy, the ball is } \\
\text { released in front of the face with } \\
\text { continued movements of the } \\
\text { hands to the front of the chest. }\end{array}$ \\
\hline 2 & $\begin{array}{c}\text { Throwing the big ball } \\
\text { with both hands } \\
\text { down. }\end{array}$ & $\begin{array}{l}\text { The child can throw the big ball with } \\
\text { feet shoulder width apart, look } \\
\text { forward, hands bent forward } \\
\text { throwing the ball, not followed by } \\
\text { body movements. }\end{array}$ & $\begin{array}{l}\text { The child can throw a big ball with } \\
\text { feet shoulder width apart, looking } \\
\text { forward, straight hands swinging } \\
\text { forward throwing the ball, not } \\
\text { followed by body movements. }\end{array}$ & $\begin{array}{c}\text { The child can throw the big ball with } \\
\text { feet shoulder width apart, looking } \\
\text { forward, straight hands swinging the } \\
\text { ball forward, followed by body } \\
\text { movements. }\end{array}$ \\
\hline 3 & $\begin{array}{l}\text { Toss the small ball } \\
\text { with one hand up. }\end{array}$ & $\begin{array}{l}\text { The child can throw a small ball, the } \\
\text { position of one foot is in front, the } \\
\text { view is forward, the body is not } \\
\text { bouncy, the ball is released above the } \\
\text { head without further hand } \\
\text { movements. }\end{array}$ & $\begin{array}{l}\text { Children can throw a small ball, } \\
\text { position one foot in front, look } \\
\text { forward, body bouncy, the ball is } \\
\text { released above the head without } \\
\text { further hand movements. }\end{array}$ & $\begin{array}{c}\text { Children can throw a small ball, } \\
\text { position one foot in front, look } \\
\text { forward, body bouncy, the ball is } \\
\text { released in front of the face with } \\
\text { continued movements of the hands to } \\
\text { the front of } \\
\text { the chest. }\end{array}$ \\
\hline 4 & $\begin{array}{c}\text { Throwing a small } \\
\text { ball with one hand } \\
\text { from below. }\end{array}$ & $\begin{array}{l}\text { The child can throw a small ball, look } \\
\text { straight, one leg in front of it is } \\
\text { opposite the hand that throws the bal } \\
\text { from below which is bent and not } \\
\text { followed by body movements. }\end{array}$ & $\begin{array}{l}\text { The child can throw a small ball, } \\
\text { looking straight, one foot in front } \\
\text { of it against the hand that throws } \\
\text { the ball from below, not followed } \\
\text { by body movements. }\end{array}$ & $\begin{array}{c}\text { The child can throw a small ball, } \\
\text { looking straight, one foot in front of it } \\
\text { against the hand that throws the ball } \\
\text { from below followed by body } \\
\text { movements. }\end{array}$ \\
\hline 5 & $\begin{array}{l}\text { Catch the big ball } \\
\text { with both hands. }\end{array}$ & $\begin{array}{l}\text { The child cannot catch the big ball } \\
\text { properly. }\end{array}$ & $\begin{array}{l}\text { The child can catch the big ball in } \\
\text { the hug position. }\end{array}$ & $\begin{array}{c}\text { The child can catch the big ball with } \\
\text { their hands in front } \\
\text { of their chest. }\end{array}$ \\
\hline 6 & $\begin{array}{c}\text { Catch the small ball } \\
\text { with both hands. }\end{array}$ & $\begin{array}{l}\text { The child cannot catch the small ball } \\
\text { properly. }\end{array}$ & $\begin{array}{l}\text { The child can catch a small ball in a } \\
\text { hug position. }\end{array}$ & $\begin{array}{c}\text { Children can catch a small ball with } \\
\text { their hands in front of the } \\
\text { chest. }\end{array}$ \\
\hline 7 & $\begin{array}{l}\text { Kick the big ball } \\
\text { forward. }\end{array}$ & $\begin{array}{l}\text { Children can kick the ball using the } \\
\text { inner leg, in a way that is not swung, } \\
\text { with an upright body position. }\end{array}$ & \begin{tabular}{|} 
The child can kick the ball using \\
the inner foot, by swinging the leg \\
from back to front, with an upright \\
body position.
\end{tabular} & $\begin{array}{c}\text { Children can kick the ball using the } \\
\text { inner foot, by swinging the leg from } \\
\text { back to front, body position following } \\
\text { the leg movements. }\end{array}$ \\
\hline 8 & $\begin{array}{l}\text { Hit the balloon } \\
\text { hanging. }\end{array}$ & $\begin{array}{l}\text { The child hits the balloon but doesn't } \\
\text { hit the target. }\end{array}$ & $\begin{array}{c}\text { The child can hit the balloon with } \\
\text { one hand opposite the foot in front, } \\
\text { looking forward, body bouncy, } \\
\text { without further movement. }\end{array}$ & $\begin{array}{c}\text { The child can hit the balloon with one } \\
\text { hand opposite the leg in front, gaze } \\
\text { forward, body bouncy, with } \\
\text { continued movements. }\end{array}$ \\
\hline
\end{tabular}




\section{Results and Discussion}

Test results data in the study are presented in three parts, the average score on each item of locomotor, nonlocomotor and manipulative basic motion. The result data presented with the aim of seeing the child's improvement in each test item and also the overall variable of movement in the child.

The following shows the data on the results of basic motion tests on 30 children in the DKI Jakarta area that are reached in the study sample. For data on each basic motion item, following are the data obtained.

Based on the information in the table 4, there is a difference between the Pre-test and Post-test results obtained that have previously been carried out in DKI Jakarta, before the application of the basic motion model based on traditional games for early childhood (5-6) years old did a pre-test or test Initially using the existing locomotor observation sheet, the pre-test results obtained the number of results for the basic locomotor motion of children obtained by 386 with an average of 12.8. After that the basic motion model based on traditional games for early childhood (5-6) years using the basic motion model based on traditional games that have been developed. After the treatment is given, the subject is tested again with the same locomotor basic motion observation sheet, and this is called the post-test which is used to determine whether there is an increase in basic locomotor motion based on traditional children's games. Based on the results of the post-test, the results were 621 with an average of 20.7 .

Table 4. Results of locomotor pre-test and post-test data

\begin{tabular}{|c|c|c|c|}
\hline Subject & Pre-Test & Post-Test & Information \\
\hline 1 & 12 & 21 & Increase \\
\hline 2 & 13 & 21 & Increase \\
\hline 3 & 11 & 21 & Increase \\
\hline 4 & 13 & 20 & Increase \\
\hline 5 & 12 & 21 & Increase \\
\hline 6 & 12 & 19 & Increase \\
\hline 7 & 12 & 21 & Increase \\
\hline 8 & 12 & 20 & Increase \\
\hline 9 & 13 & 21 & Increase \\
\hline 10 & 14 & 21 & Increase \\
\hline 11 & 12 & 21 & Increase \\
\hline 12 & 14 & 21 & Increase \\
\hline 13 & 15 & 21 & Increase \\
\hline 14 & 13 & 21 & Increase \\
\hline 15 & 11 & 19 & Increase \\
\hline 16 & 12 & 21 & Increase \\
\hline 17 & 14 & 21 & Increase \\
\hline 18 & 13 & 21 & Increase \\
\hline 19 & 14 & 21 & Increase \\
\hline 20 & 12 & 20 & Increase \\
\hline 21 & 14 & 21 & Increase \\
\hline 22 & 12 & 20 & Increase \\
\hline 23 & 13 & 21 & Increase \\
\hline 24 & 12 & 20 & Increase \\
\hline 25 & 14 & 21 & Increase \\
\hline 26 & 15 & 21 & Increase \\
\hline 27 & 14 & 21 & Increase \\
\hline 28 & 12 & 21 & Increase \\
\hline 29 & 12 & 21 & Increase \\
\hline 30 & 14 & 21 & Increase \\
\hline Total & 386 & 621 & Increase \\
\hline verage Value & 12.8 & 20.7 & Increase \\
\hline
\end{tabular}


The final result of the basic motion model product based on traditional games for early childhood (5-6) years after the research was carried out. It can be concluded that the basic motion model based on traditional games that is applied is feasible and suitable for use for early childhood (5-6) years and is effective for early childhood (5-6) years.

Based on the information in the table 5 , there is a difference between the Pre-test and Post- test results obtained which have previously been carried out in DKI Jakarta, before the application of the basic motion model based on traditional games for early childhood (5-6) years old did a pre-test or test Initially using the existing non-locomotor observation sheet, the pre-test results showed that the number of results for children's non-locomotor basic motion was 410 with an average of 13.66. After that the basic motion model based on traditional games for early childhood (5-6) years using the basic motion model based on traditional games that have been developed. After the treatment is given, the subject is tested again with the same non-locomotor basic motion observation sheet, and this is called the post-test which is used to determine whether there is an increase in non-locomotor basic motion based on traditional children's games. Based on the results of the post-test, the results obtained were 505 with an average of 16.83 .

The final result of the basic motion model product based on traditional games for early childhood (5-6) years after the research was carried out. It can be concluded that the basic motion model based on traditional games that is applied is feasible and suitable for use for early childhood (5-6) years and is effective for early childhood (5-6) years.

Table 5. Results of nonlocomotor pre-test and post-test data

\begin{tabular}{|c|c|c|c|}
\hline Subject & Pre-Test & Post-Test & Information \\
\hline 1 & 15 & 17 & Increase \\
\hline 2 & 13 & 17 & Increase \\
\hline 3 & 11 & 16 & Increase \\
\hline 4 & 15 & 16 & Increase \\
\hline 5 & 14 & 16 & Increase \\
\hline 6 & 14 & 15 & Increase \\
\hline 7 & 12 & 16 & Increase \\
\hline 8 & 12 & 17 & Increase \\
\hline 9 & 14 & 16 & Increase \\
\hline 10 & 14 & 17 & Increase \\
\hline 11 & 13 & 17 & Increase \\
\hline 12 & 17 & 18 & Increase \\
\hline 13 & 15 & 17 & Increase \\
\hline 14 & 13 & 18 & Increase \\
\hline 15 & 11 & 15 & Increase \\
\hline 16 & 12 & 18 & Increase \\
\hline 17 & 14 & 16 & Increase \\
\hline 18 & 14 & 17 & Increase \\
\hline 19 & 14 & 18 & Increase \\
\hline 20 & 12 & 17 & Increase \\
\hline 21 & 15 & 16 & Increase \\
\hline 22 & 13 & 17 & Increase \\
\hline 23 & 13 & 16 & Increase \\
\hline 24 & 16 & 18 & Increase \\
\hline 25 & 15 & 17 & Increase \\
\hline 26 & 16 & 18 & Increase \\
\hline 27 & 14 & 17 & Increase \\
\hline 28 & 12 & 17 & Increase \\
\hline 29 & 15 & 18 & Increase \\
\hline 30 & 12 & 17 & Increase \\
\hline Total & 410 & 505 & Increase \\
\hline jerage Value & 13.66 & 16.83 & Increase \\
\hline
\end{tabular}


Table 6. Results of manipulative pre- test and post-test data

\begin{tabular}{|c|c|c|c|}
\hline Subject & Pre-Test & Post-Test & Information \\
\hline 1 & 20 & 24 & Increase \\
\hline 2 & 21 & 24 & Increase \\
\hline 3 & 20 & 23 & Increase \\
\hline 4 & 16 & 20 & Increase \\
\hline 5 & 17 & 22 & Increase \\
\hline 6 & 16 & 19 & Increase \\
\hline 7 & 19 & 22 & Increase \\
\hline 8 & 19 & 23 & Increase \\
\hline 9 & 23 & 24 & Increase \\
\hline 10 & 22 & 23 & Increase \\
\hline 11 & 22 & 23 & Increase \\
\hline 12 & 19 & 22 & Increase \\
\hline 13 & 20 & 23 & Increase \\
\hline 14 & 19 & 22 & Increase \\
\hline 15 & 20 & 23 & Increase \\
\hline 16 & 20 & 23 & Increase \\
\hline 17 & 18 & 20 & Increase \\
\hline 18 & 19 & 23 & Increase \\
\hline 19 & 21 & 22 & Increase \\
\hline 20 & 18 & 20 & Increase \\
\hline 21 & 17 & 23 & Increase \\
\hline 22 & 18 & 23 & Increase \\
\hline 23 & 19 & 22 & Increase \\
\hline 24 & 23 & 24 & Increase \\
\hline 25 & 22 & 23 & Increase \\
\hline 26 & 19 & 22 & Increase \\
\hline 27 & 22 & 23 & Increase \\
\hline 28 & 21 & 22 & Increase \\
\hline 29 & 21 & 23 & Increase \\
\hline 30 & 20 & 22 & Increase \\
\hline Total & 591 & 672 & Increase \\
\hline verage Value & 19.7 & 22.4 & Increase \\
\hline
\end{tabular}

Based on the information in the table 6, there is a difference between the Pre-test and Post- test results obtained that have previously been carried out in DKI Jakarta, before the application of the basic motion model based on traditional games for early childhood (5-6) years old did a pre-test or test Initially using the existing manipulative observation sheet, the pre-test results obtained the number of results for the basic manipulative movements of children obtained by 591 with an average of 19.7. After that the basic motion model based on traditional games for early childhood (5-6) years using the basic motion model based on traditional games that have been developed. After the treatment is given, the subject is tested again with the same manipulative basic motion observation sheet, and this is called the post-test which is used to find out whether there is an increase in manipulative basic motion based on traditional children's games. Based on the results of the post- test, the results were 672 with an average of 22.4.

The final result of the basic motion model product based on traditional games for early childhood (5-6) years after the research was carried out. It can be concluded that the basic motion model based on traditional games that is applied is feasible and suitable for use for early childhood (5-6) years and is effective for early childhood (5-6) years.

John N. Drowtzky (1975) ${ }^{2}$ states as follows: "Learning movement is learning that is realized through muscular responses that are expressed in body movements or body parts." The main purpose of moving is to improve movement skills. Understanding movements is only a goal that must be followed in order to master skill movements,

\footnotetext{
${ }^{2}$ Drowatzky, John, N. (1975). Motor Learning Princples And Practice. Minneapolis: Burger Publishing Company.
} 
both imitating and self- created.

The results of research by experts show that an early age is a period that is truly very valuable for children, and is right to instill a personality foundation, therefore early childhood is called the golden age, which is a very decisive period for the success of educators at school age, adolescence, adulthood and so on.

In connection with basic movements based on traditional games from 30 DKI Jakarta children, it describes how to improve basic locomotor, non-locomotor and manipulative movement skills. Children who are actively moving with good basic movement results give a temporary picture that they are healthy because they are able to move actively by displaying their abilities through traditional games. To measure more deeply the level of basic movement whether it is proven that it shows good results, it is also necessary to do more in-depth study and collaborate with researchers who have the capacity to be able to diagnose and measure their health level in depth.

\section{Conclusions}

Based on the research results obtained 20 basic motion models based on traditional early childhood games (5-6) years which in the small trial involved 10 research subjects and in the large trial 30 research subjects. Based on the results of the effectiveness test on 30 research subjects, the initial test results of the basic locomotor motion of the children obtained an average of 12.85 and the final test obtained 20.71, there was an increase in locomotor. The results of the non- locomotor preliminary test for children obtained an average of 13.66 and the final test obtained 16.83, then there was an increase in non-locomotor. The results of the initial manipulative test of children obtained an average of 19.71 and the final test obtained 22.42, so there was an increase in manipulatives. Based on the results of the research above, the researcher can draw the conclusion that the basic motion model based on traditional games can be applied and can increase the activity of basic movements for early childhood (5-6) years.

\section{REFERENCES}

[1] Borg W. R, \& Gall M. D. (1983). Educational Research: An Introduction. Fourth Edition (New York: Longman,), h.775

[2] Drowatzky, John, N. (1975). Motor Learning Princples and Practice. Minneapolis: Burger Publishing Company.

[3] Australian preschool children. Journal of Science and Medicine in Sport, 13(5), 503-508. https://doi.org/10.1016/j .jsams.2009.05.010

[4] Hayati, H. S., Myrnawati, C., \& Asmawi, M. (2017). Effect of traditional games, learning motivation and learning style on childhoods gross motor skills. International Journal of Education and Research, 5(7), 53-66.

[5] Hyde, K. L., Lerch, J., Norton, A., Forgeard, M., Winner, E., Evans, A. C., \& Schlaug, G. (2009). The effects of musical training on structural brain development: A longitudinal study. Annals of the New York Academy of Sciences, 1169, 182-186. https://doi.org/10.1111/j.1749-6632.2009.04852.x

[6] Kokštejn, J., Musálek, M., Št’astný, P., \& Golas, A. (2017). Fundamental motor skills of Czech children at the end of the preschool period. Acta Gymnica, 47(4), 193-200. https://doi.org/10.5507/ag.2017.024

[7] Lemos, A. G., Avigo, E. L., \& Barela, J. A. (2012). Physical Education in Kindergarten Promotes Fundamental Motor Skill Development. Advances in Physical Education, 02(01), 17- 21. https://doi.org/10.4236/ape.2012.21003

[8] Lykesas, G., Tsapakidou, A., \& Tsompanaki, E. (2014). Creative Dance as a Means of Growth and Development of Fundamental Motor Skills for Children in First Grades of Primary Schools in Greece. Asian Journal of Humanities and Social Studies, 02(01), 211-218. Retrieved from

[9] Zulfahmi, M. N. (2019). Basic movement dancing skills of 5-6 years old children through dance and sing theme based learning with demonstration method. 8(1), 30-36. 